\title{
Doped microporous hybrid silica membranes for gas separation
}

\author{
Hammad F. Qureshi ${ }^{1} \cdot$ Rogier Besselink $^{2} \cdot$ Johan E. ten Elshof $^{2} \cdot$ Arian Nijmeijer $^{1}$. \\ Louis Winnubst ${ }^{1}$
}

Received: 27 January 2015/Accepted: 17 March 2015/Published online: 31 March 2015

(C) The Author(s) 2015. This article is published with open access at Springerlink.com

\begin{abstract}
Hybrid silica (i.e., bis-triethoxysilylethane: BTESE) membranes doped with $\mathrm{B}$, $\mathrm{Ta}$ or $\mathrm{Nb}$ were made through a sol-gel process. Triethyl borate, tantalum (V) ethoxide (TPE) and niobium (V) ethoxide (NPE) were selected as doping precursors. The doping concentration was optimized to produce sols, suitable for membrane fabrication. Thermal stability, structural analysis, crosssectional micrographs and single gas permeation experiments were performed on these membranes, and results are compared with an undoped BTESE membrane. It was observed that the synthesized doped BTESE materials and membranes resulted into a more open (and, in one occurrence, $\mathrm{SF}_{6}$ permeable) pore microstructure, showing high permeances of larger gas molecules, while having a crosssectional thickness comparable to undoped BTESE membranes.
\end{abstract}

Louis Winnubst

a.j.a.winnubst@utwente.nl;

http://www.utwente.nl/tnw/im

1 Inorganic Membranes, MESA+ Institute for

Nanotechnology, University of Twente, P. O. Box 217,

7500 AE Enschede, The Netherlands

2 Inorganic Materials Science (IMS), MESA+ Institute for Nanotechnology, University of Twente, P. O. Box 217, 7500 AE Enschede, The Netherlands
Graphical Abstract
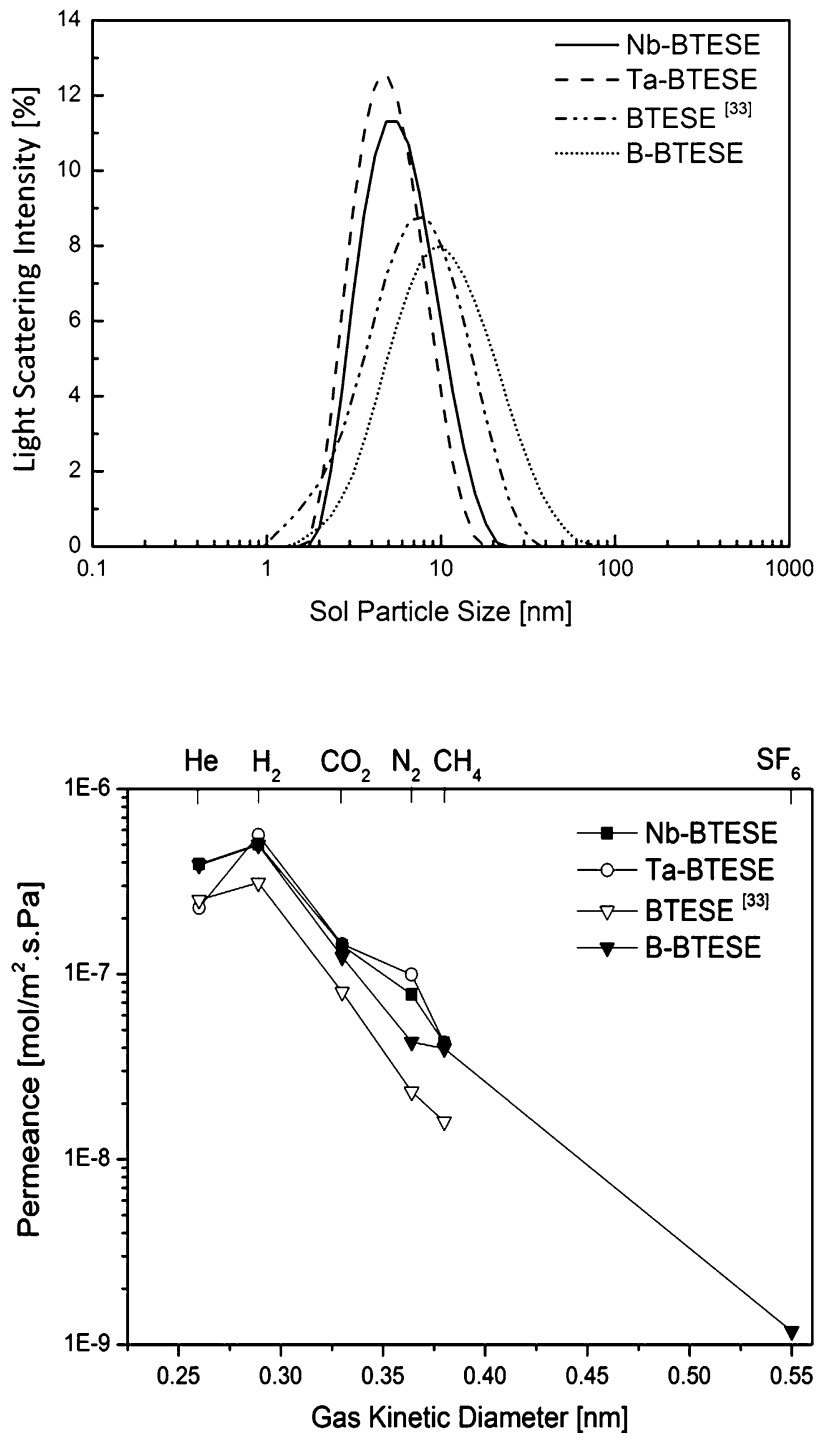

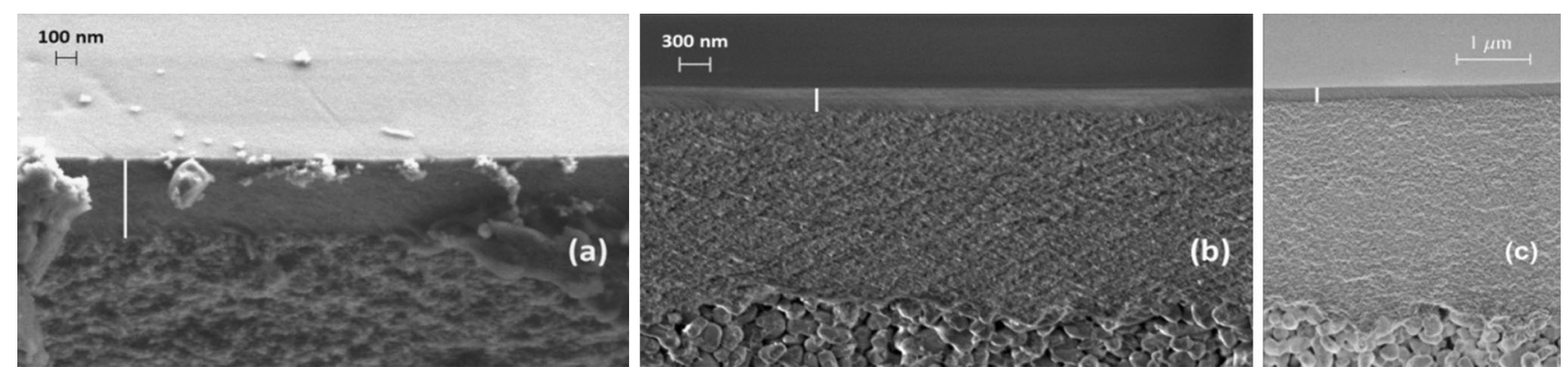

Keywords Sol-gel synthesis - Microporous membranes · Hybrid silica $\cdot$ Metal doping · Gas separation

\section{Introduction}

Inorganic membranes have attracted considerable attention for their applicability in gas separation processes in conditions where polymeric membranes cannot be used. Inorganic membranes remain stable at high temperature (i.e., $>400{ }^{\circ} \mathrm{C}$ ), do not swell in solvents, and are resistant to abrasion $[1,2]$. Porous inorganic membranes with either size- and/or affinity-based selectivity offer potential advantages in separating gaseous mixtures at elevated temperatures [3], in catalytic membrane reactors [4] and in hydrogen separation [5]. The application of microporous silica membranes for hydrogen purification has been subject of study for a long time [4]. These membranes are either prepared by a chemical vapor deposition (CVD) technique [6,7] or by using sol-gel methods [8-10]. Although silica membranes, fabricated by sol-gel methods, show great promise in gas separation, the technical challenges such as hydrothermal stability are still a point of concern [11]. Hybrid organosilica (e.g., bis-triethoxysilylethane: BTESE) membranes are very suitable to overcome such problems, since they show an improved hydrothermal stability $[12,13]$. The exposure of silica to moisture (or steam) at around $70{ }^{\circ} \mathrm{C}$ leads to the hydrolysis of $\mathrm{Si}-\mathrm{O}-\mathrm{Si}$ bonds [1]. The introduction of organic bridges in the silica microstructure makes it less susceptible for hydrolysis which extends the industrial application of silica membranes [14]. It has been reported that the shape, flexibility and length of organic bridges in the hybrid silica network have an influence on the membrane pore size, structure and affinity [15].

For a gas permselective membrane, the pore size and pore size distribution should be small and sufficiently uniform to ensure that the membrane acts as an efficient sieve to block larger gas molecules for permeating through the membrane. The presence of hydrocarbon chains in the silica backbone improves the hydrothermal stability of such a hybrid silica matrix, however, at the cost of reduced gas selectivity [11]. A possible approach to improve the gas permselectivity of these hybrid silica membranes is the incorporation of metal ions in the hybrid silica matrix. This approach was successfully implemented by doping the silica network with metal ions, such as aluminum and magnesium [16], zirconium [17, 18], niobium [19, 20], nickel [21] and cobalt [22, 23]. For hybrid silica (i.e., BTESE), only the incorporation of niobia has been reported to date [24, 25], where it is claimed that the introduction of niobia created surface active sites resulting in a reduced $\mathrm{CO}_{2}$ permeance. These authors observed that the $\mathrm{H}_{2} / \mathrm{CO}_{2}$ permselectivity at $450{ }^{\circ} \mathrm{C}$ was higher (i.e., $\mathrm{H}_{2} / \mathrm{CO}_{2}=220$ ) compared to hydrogen selectivity over larger molecule such as nitrogen $\left(\mathrm{H}_{2} / \mathrm{N}_{2}=125\right)$ and thus claiming that $\mathrm{CO}_{2}$ permeance through these Nb-BTESE membranes was not only determined by size exclusion. However, in the same work, this enhanced $\mathrm{H}_{2} / \mathrm{CO}_{2}$ permselectivity was not observed at $300{ }^{\circ} \mathrm{C}$ and $350{ }^{\circ} \mathrm{C}\left[\left(\mathrm{H}_{2} / \mathrm{CO}_{2}\right)_{300}{ }^{\circ} \mathrm{C}=11.4,\left(\mathrm{H}_{2} /\right.\right.$ $\left.\mathrm{CO}_{2}\right)_{350}{ }^{\circ} \mathrm{C}=11, \quad\left(\mathrm{H}_{2} / \mathrm{CO}_{2}\right)_{400}{ }^{\circ} \mathrm{C}=50 ; \quad\left(\mathrm{H}_{2} / \mathrm{N}_{2}\right)_{300}{ }^{\circ} \mathrm{C}=$ 50, $\left.\left(\mathrm{H}_{2} / \mathrm{N}_{2}\right)_{350}{ }^{\circ} \mathrm{C}=45,\left(\mathrm{H}_{2} / \mathrm{N}_{2}\right)_{400}{ }^{\circ} \mathrm{C}=65\right]$ which raises questions regarding niobia incorporation, its influence on reduced $\mathrm{CO}_{2}$ permeance and the reproducibility in fabrication of Nb-BTESE membranes. Because of this inconsistency in results, a new study on Nb-doped BTESE was performed as described in this study.

Furthermore, we report the incorporation of boron and tantalum in the hybrid silica (BTESE) matrix with the aim to fabricate a defect-free, gas selective membrane film. Boron has extensively been used as a glass-forming agent due to their low thermal expansion coefficient. In membrane fabrication, boron has been doped in a silica matrix using boric acid powder as boron source to reduce the defect density and enhance the membrane performance [26]. The $\mathrm{Si}-\mathrm{C}-\mathrm{C}-\mathrm{Si}$ bond strength of hybrid silica is unknown, but in silica, $\mathrm{Si}-\mathrm{O}$ has a bond strength of $368 \mathrm{~kJ} / \mathrm{mol}$ [27] and the bond $\mathrm{B}-\mathrm{O}$ strengths are $560 \mathrm{~kJ} / \mathrm{mol}$ and $790 \mathrm{~kJ} / \mathrm{mol}$ for $\mathrm{BO}_{4}{ }^{-}$and $\mathrm{BO}_{3}$ species, respectively [27]. The incorporation of boron in the hybrid silica matrix was expected to bring more rigidity and tightness to hybrid silica matrix. In this research, triethylborate (TEB) was used as a boron source for doping the hybrid silica matrix. 
Tantalum is known for its high chemical and hydrothermal stability and belongs to the refractory metal group [28]. Thin films of tantalum oxide are already in use in transistors [29], sensors [30], and capacitors [31]. It has been reported that sol-gel-derived ultra-thin tantalum membranes resulted in a dense structure with very low hydrogen permeance [32]. On the other hand, hybrid silica membranes have a relatively loose pore microstructure [33]. In the current work, tantalum is used as a dopant in hybrid silica, to form a relatively denser microstructure than that of undoped BTESE [33] for improved $\mathrm{H}_{2} / \mathrm{X}$ gas permselectivities.

\section{Experimental}

As hybrid silica precursor, 1,2-bis(triethoxysilyl) ethane (BTESE) (97\%, ABCR Germany) was used. Triethyl borate (TEB) $\left(\mathrm{B}\left(\mathrm{OC}_{2} \mathrm{H}_{5}\right)_{3}, 99 \%\right.$, Aldrich), niobium (V) ethoxide (NPE) $\left(\mathrm{Nb}\left(\mathrm{OC}_{2} \mathrm{H}_{5}\right)_{5}, 99.99 \%\right.$, ABCR Chemicals) and tantalum (V) ethoxide (TPE) $\left(\mathrm{Ta}\left(\mathrm{OC}_{2} \mathrm{H}_{5}\right)_{5}\right.$, $99 \%$, ABCR Chemicals) were used as boron, niobium and tantalum sources, respectively.

For the synthesis of boron-doped hybrid silica (BBTESE) sols, the following procedure was used. TEB $(2.51 \mathrm{ml})$ was added to a BTESE-ethanol mixture $(11.10 \mathrm{ml}$ BTESE in $6.38 \mathrm{ml}$ ethanol) in a round bottom flask. Into that flask, a mixture of nitric acid $(0.5 \mathrm{ml}$, $65 \mathrm{wt} \%$ Aldrich), water (3.65 ml, deionized) and ethanol (15.85 ml, Absolute, Aldrich) was added under vigorous stirring in an ice bath and afterward kept at $60{ }^{\circ} \mathrm{C}$ for $1.5 \mathrm{~h}$. The sol contained 20 at.\% B $(=[\mathrm{B}] /[\mathrm{B}+\mathrm{Si}])$. The final molar ratio of sol w.r.t. BTESE/TEB/EtOH/ $/ \mathrm{HNO}_{3} / \mathrm{H}_{2} \mathrm{O}$ was 1.0/0.5/37.005/0.25/7.51, respectively.

The hydrolysis step for the synthesis of tantalum-doped hybrid silica (Ta-BTESE) sols was performed in a glove box under nitrogen atmosphere. A solution of $0.495 \mathrm{ml}$ nitric acid ( $\mathrm{pH} 2.56$ ) in $12.25 \mathrm{ml}$ ethanol was added to a BTESE-ethanol mixture $(3.26 \mathrm{ml}$ BTESE in $9.44 \mathrm{ml}$ ethanol) and stirred for $2 \mathrm{~h}$ at $20{ }^{\circ} \mathrm{C}$. TPE $(1.11 \mathrm{ml}$ in $40.77 \mathrm{ml}$ ethanol) was added to the aforementioned solution, and the reaction was further allowed to run for $1 \mathrm{~h}$ at $20{ }^{\circ} \mathrm{C}$ under constant vigorous stirring. Finally, $0.43 \mathrm{ml}$

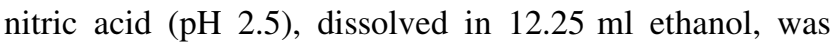
added to the doped hybrid silica mixture, and the reaction was allowed to run at $60{ }^{\circ} \mathrm{C}$ for another $1 \mathrm{~h}$. The TaBTESE hybrid sol contained $20 \% \mathrm{Ta}(=[\mathrm{Ta}] /[\mathrm{Ta}+\mathrm{Si}])$. The final molar ratio of sol w.r.t. BTESE/TPE/EtOH/ $\mathrm{HNO}_{3} / \mathrm{H}_{2} \mathrm{O}$ was 1.0/0.5/61.49/0.0003/6.0, respectively.

Niobium-doped hybrid silica (Nb-BTESE) sols were made by using the following reaction scheme. A solution of $0.46 \mathrm{ml}$ nitric acid $(\mathrm{pH} 2.5)$ in $12.25 \mathrm{ml}$ of ethanol was added to a BTESE-ethanol mixture (3.26 ml BTESE in
$9.44 \mathrm{ml}$ ethanol) in a glove box under nitrogen atmosphere. The solution was stirred at $20^{\circ} \mathrm{C}$ for $2 \mathrm{~h}$. After that, $1.05 \mathrm{ml} \mathrm{NPE}$ in $40.83 \mathrm{ml}$ ethanol was added to the solution, and the reaction was allowed to run for $1 \mathrm{~h}$ at $20^{\circ} \mathrm{C}$ under constant vigorous stirring. Finally, $0.43 \mathrm{ml}$ nitric acid, dissolved in $12.25 \mathrm{ml}$ ethanol, was added to the solution, and the reaction was allowed to run at $60{ }^{\circ} \mathrm{C}$ for $1 \mathrm{~h}$ under reflux. The Nb-BTESE hybrid sol contained $20 \mathrm{~mol} \% \mathrm{Nb}(=[\mathrm{Nb}] /[\mathrm{Nb}+\mathrm{Si}])$. The final molar ratio of sol w.r.t. BTESE/NPE/EtOH/ $\mathrm{HNO}_{3} / \mathrm{H}_{2} \mathrm{O}$ was $1.0 / 0.5 /$ 61.39/0.0003/6.0, respectively.

Figure 1 presents a schematic description of the TaBTESE and Nb-BTESE sol synthesis procedure. When not applied immediately after synthesis, doped BTESE sols were stored at $-28{ }^{\circ} \mathrm{C}$. For membrane dip coating, the sols were diluted six times by volume with ethanol resulting in a final concentration of $0.3 \mathrm{M}([\mathrm{Si}]+[\mathrm{M}])$.

Particle sizes of freshly prepared hybrid sols (with an extra $75 \%$ dilution in ethanol by volume) were determined by dynamic light scattering (DLS) using a Malvern Zetasizer Nano ZS at $25^{\circ} \mathrm{C}$. Measurements were taken using 1.0$1.5 \mathrm{ml}$ of the sol in a disposable size cuvette (Type DTS0012, Malvern Instruments). The hydrodynamic diameter of the sol particles was determined from the Brownian motion of the particles as defined by the translational diffusion coefficient $D$ in the ethanol solvent. The hydrodynamic diameter $d$ was obtained by the Stokes-Einstein equation:

$d=k T / 3 \pi \eta D$

where $k=$ Boltzmann's constant; $T=$ the temperature; $\eta=$ solvent viscosity; $D=$ diffusion coefficient in the solvent.

Disc-shaped $\alpha$-alumina supported $\gamma$-alumina was prepared by a dip-coating procedure of a boehmite sol on $\alpha$ alumina supports (support thickness of $2.08 \pm 0.01 \mathrm{~mm}$ and pore diameter of about $100 \mathrm{~nm}$, Pervatech B.V, The Netherlands), followed by subsequent drying and calcination, as described in detail in [34]. The dip-coating calcination process was performed twice on the $\alpha$-alumina disc supports to form a smooth mesoporous intermediate layer. A pore size for the $\gamma$-alumina intermediate layer of 3-5 nm was determined by permporometry, using the method as described elsewhere [35].

For membrane fabrication, the separation layer was applied onto the $\alpha$-alumina supported $\gamma$-alumina substrate by a single dipping procedure as described elsewhere [33], followed by a thermal treatment at $300{ }^{\circ} \mathrm{C}$ for $3 \mathrm{~h}$ under nitrogen (99.99\% pure) with a heating/cooling rate of $0.5^{\circ} \mathrm{C} / \mathrm{min}$. The sol and membrane fabrication experiments were performed three to five times to confirm the reproducibility of the results.

The thickness of the calcined hybrid silica layers was determined by analyzing cross-sectional micrographs of 


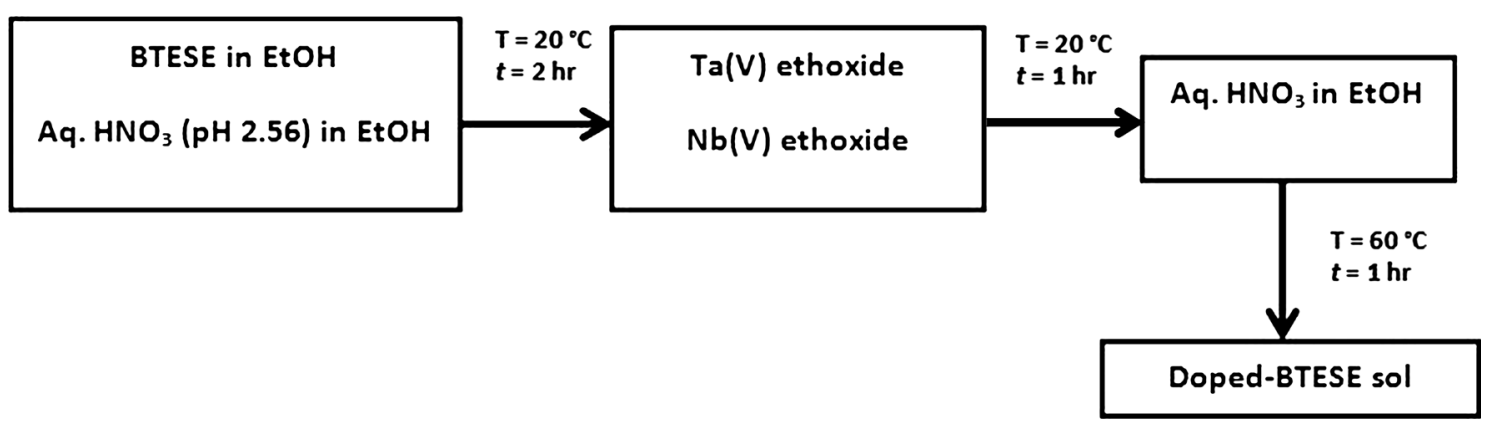

Fig. 1 Sol fabrication scheme of niobia and tantalum-doped BTESE sols

the membranes, acquired from a high-resolution scanning electron microscope HR-SEM (Zeiss 1550) at an accelerating voltage of $1.0 \mathrm{kV}$.

Dried powders of doped hybrid silica sols were obtained by drying the corresponding sols in a petri dish overnight at room temperature. These powders were analyzed using thermogravimetry (TGA). Measurements were carried out on a STA 449 F3 Jupiter ${ }^{\circledR}$ (Netzsch) instrument under nitrogen atmosphere. About $20 \mathrm{mg}$ of sample was used and each measurement run from room temperature until at least $800{ }^{\circ} \mathrm{C}$ at a heating rate of $10^{\circ} \mathrm{C} / \mathrm{min}$.

The in situ Fourier transform infrared (FTIR) measurements were taken in the sol solution by using a Bruker Tensor 27 equipped with a KBr beamsplitter, a Pike GladiATR diamond attenuated total reflectance (ATR) unit and a liquid nitrogen cooled MCT broadband detector. The FTIR spectra were recorded in $2 \mathrm{~min}$, with a resolution of $1 \mathrm{~cm}^{-1}$. The Fourier transform (FT) was performed with 9480 phase interferogram points and a Blackman-Harris 3-term apodization function. The ATR-unit was equipped with an aluminum cup being sealed with a rubber stop.

For the in situ FTIR measurements, $129 \mu \mathrm{L}$ BTESE was dissolved in $2371 \mu \mathrm{L}$ ethanol in a $5 \mathrm{~mL}$ polypropylene tube. In a separate tube, $37 \mu \mathrm{L}$ HNO3 in water $(\mathrm{pH}=2.56)$ was mixed in $2464 \mu \mathrm{L}$ ethanol. The second tube containing nitric acid was poured into the first tube with BTESE vigorously shaken for $30 \mathrm{~s}$, and subsequently, $300 \mu \mathrm{L}$ of this solution was placed in the aluminum cup onto the ATR-unit, and the measurement was started. The FTIR spectra of calcined undoped and doped hybrid silica powders were obtained in the range $400-4000 \mathrm{~cm}^{-1}$, using a resolution of $4 \mathrm{~cm}^{-1}$ and 16 scans.

Membrane characterization was performed on an inhouse designed single gas permeation (SGP) setup in a deadend mode without backpressure. The membranes were sealed in a stainless steel module using Viton ${ }^{\circledR} 51414$ O-rings with the separation layer exposed to the feed side. The gas permeance was measured at $200{ }^{\circ} \mathrm{C}$ in a sequence, starting with the gas of smallest kinetic diameter, from $\mathrm{He}$ $(0.255 \mathrm{~nm}), \mathrm{H}_{2}(0.289 \mathrm{~nm}), \mathrm{N}_{2}(0.364 \mathrm{~nm}), \mathrm{CO}_{2}(0.33 \mathrm{~nm})$,
$\mathrm{CH}_{4}(0.389 \mathrm{~nm})$ to $\mathrm{SF}_{6}(0.55 \mathrm{~nm})$ and $\mathrm{H}_{2}$ (again) at $200{ }^{\circ} \mathrm{C}$ with a trans-membrane pressure of 2 bar. The $\mathrm{H}_{2}$ permeance measurements were taken again at the end of all measurements to ensure stable membrane microstructure. Only a 1-3\% variation in $\mathrm{H}_{2}$ permeance was observed between the two measurements.

Membrane performance via SGP was determined by:

$F_{i}=\frac{N_{i}}{\Delta P}$

where $F$ is the permeance of gas $i$, determined by calculating the molar flux $(N)$ of the gas through the membrane at a pressure difference $(\Delta P)$ between feed and permeate side.

\section{Results and discussions}

\subsection{Doped BTESE sol characterization}

The sol fabrication of B-BTESE was a relatively straightforward synthesis scheme. However, only $20 \%$ boron doping was possible for realizing stable sols with appropriate particle sizes, necessary for membrane fabrication. Lower boron concentrations (i.e., 5, 10, and $15 \%$ ) resulted in sol particles with an average size smaller than $4 \mathrm{~nm}$ with high polydispersity. $20 \%$ doping of TEB in BTESE showed to be sufficient to synthesize uniform bigger sol particles (of about $8 \mathrm{~nm}$ ) which were applicable for membrane coating. It might be possible that more than $20 \%$ of TEB doping in the BTESE precursor during the sol synthesis would also lead to doped hybrid silica sols, suitable for membrane fabrication, but in this work, a maximum of only $20 \%$ doping was employed.

During the synthesis of hybrid silica sols, containing the ethoxides of niobium or tantalum, the system gelled within minutes when adding these ethoxides at the same time to the reaction mixture as the BTESE precursor, while a welldefined sol with a small and homogeneous particle size distribution was obtained for pure BTESE under identical 
conditions (i.e., temperature of $60{ }^{\circ} \mathrm{C}$ ) [33]. As the reactivity of the tantalum and niobium precursors is very high, an alternative route was developed to control hydrolysis/condensation during sol synthesis. This procedure not only resulted in the incorporation of these metal ion in the hybrid silica structure but also resulted in a homogenous sol particle size distribution with sizes slightly larger than (or equal to) the $\gamma$-alumina pore size of about $5 \mathrm{~nm}$. Preliminary experiments confirmed that the metal precursors hydrolyze very fast; hence, hydrolysis must be done under water lean conditions to enhance the possibility of their integration in the hybrid silica matrix. To investigate this, in situ FTIR analysis was performed during the synthesis of a (undoped) BTESE sol at $20^{\circ} \mathrm{C}$. The evolution of different reactive groups and hydrolysis products as function of reaction time was examined by monitoring the changes in intensities of its specific IR vibration lines, as shown in Fig. 2. From this figure, it can be observed that the intensities of the $\mathrm{Si}-\mathrm{O}-\mathrm{Si}$ remained relatively constant for an extended period of time. During the first $120 \mathrm{~min}$ of reaction the IR peaks, corresponding to the BTESE ethoxy groups ( $\mathrm{SiOEt}$ ) as well as the one representative for (free) water decreased in intensity, while the intensity of the $\mathrm{Si}-$ $\mathrm{OH}$ vibration (corresponding to the hydrolysis product) increased simultaneously. After around $2 \mathrm{~h}$ of reaction, the free water line intensity increased slightly, which can be ascribed as a water condensation reaction where water is released as a by-product [9]. This FTIR analysis might not provide accurate information, but it gives an indication that hydrolysis of BTESE at $20{ }^{\circ} \mathrm{C}$ proceeds in $2 \mathrm{~h}$. The combination of the lower amount of water in the reaction mixture and of already (partly) hydrolysis of BTESE after $2 \mathrm{~h}$ of reaction might sufficiently prevent the $\mathrm{Nb}$ - or $\mathrm{Ta}-$ alkoxide precursors from fast hydrolysis and enhance the

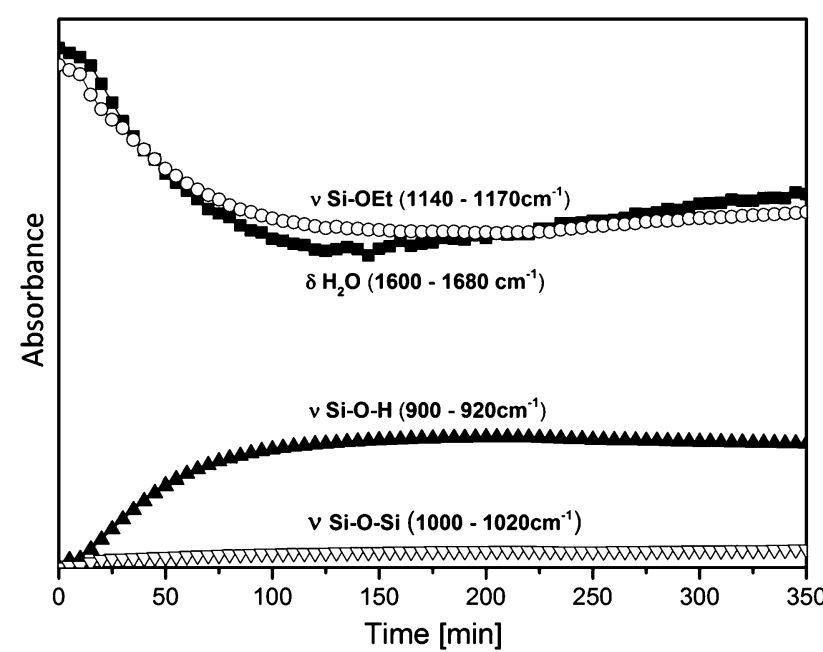

Fig. 2 Variation in the absorbance intensity of IR-vibrations related to the hydrolysis of BTESE precursor at $20{ }^{\circ} \mathrm{C}$ reaction of the metal ion with the BTESE hybrid silica precursor.

The synthesis recipe for $\mathrm{Nb}$ - and Ta-doped BTESE sols was modified accordingly, in a way as shown in Fig. 1, to obtain a sol with uniform particle size and particle size distribution, applicable for membrane coating. BTESE and aqueous $\mathrm{HNO}_{3}$ were allowed to react inside a glove box for $2 \mathrm{~h}$ at $20^{\circ} \mathrm{C}$ as a pre-hydrolysis step before the addition of either $\mathrm{Ta}$ - or $\mathrm{Nb}$-alkoxide. In this way, the dopants are allowed to react with the hybrid silica matrix under water lean conditions, which is also suitable for a homogenous dispersion of the dopant in the hybrid silica matrix [36]. Finally, after $1 \mathrm{~h}$, the remaining nitric acid was added and the temperature was increased to $60{ }^{\circ} \mathrm{C}$ to ensure complete hydrolysis of all ethoxy groups and to facilitate the condensation process. This resulted in hybrid sols with high monodispersity and average particle size of about $6 \mathrm{~nm}$ for Ta-BTESE and about $7 \mathrm{~nm}$ for Nb-BTESE-derived sols (Fig. 3).

Figure 4 shows the TGA data of dried pure and doped BTESE hybrid gels in nitrogen atmosphere. The color of the pure and all doped hybrid silica gels changed from initially white into black or dark brown after the TGA measurement, indicating pyrolysis of the samples during heating up to $800{ }^{\circ} \mathrm{C}$. The continuous weight loss up to $200{ }^{\circ} \mathrm{C}$ for pure BTESE, Nb-BTESE and Ta-BTESE gels and up to about $150{ }^{\circ} \mathrm{C}$ for B-BTESE can be assigned to the evaporation of residual water and ethanol. After this evaporation step, a slight weight loss is observed until $550{ }^{\circ} \mathrm{C}$, which is assigned to a continuous decomposition (partial pyrolysis), followed by a stronger weight loss after $550{ }^{\circ} \mathrm{C}$, which can be ascribed to the degradation of the ethylene bridge [37]. This weight loss observed at high

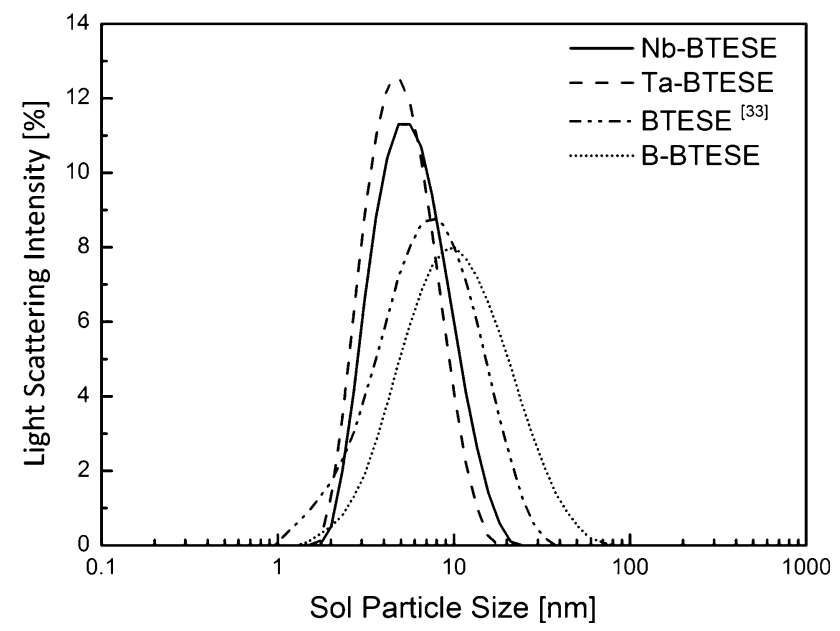

Fig. 3 Average sol particle size and size distribution of freshly synthesized doped BTESE sols, by using the light scattering technique. The sol particle size is compared with undoped BTESE sol [33] 


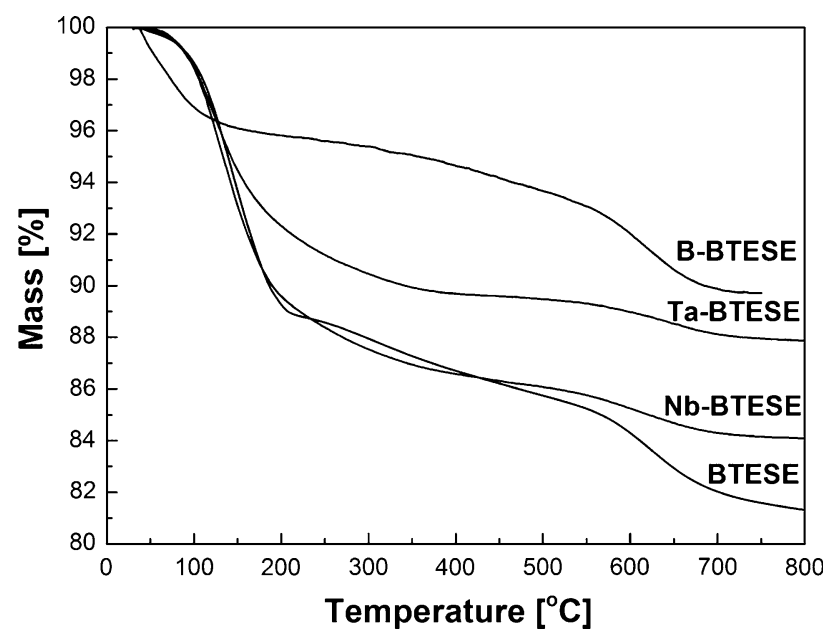

Fig. 4 Thermo-gravimetric analysis (TGA) data of undoped BTESE and doped (TEB, Ta and Nb) BTESE dried gels recorded under nitrogen atmosphere

temperature is more pronounced for the undoped and B-doped BTESE than for the Ta- or Nb-BTESE systems.

No clear explanation is available in the literature for the onset of the degradation of $-\mathrm{C}_{2} \mathrm{H}_{4}-$ in the hybrid silica precursor. In Ref. [37], it is claimed that the decomposition of the ethylene bridge in BTESE occurs between 470 and $800{ }^{\circ} \mathrm{C}$ in a nitrogen atmosphere. This is in good agreement with the results as depicted in Fig. 4. It can be claimed that a temperature of around $500{ }^{\circ} \mathrm{C}$ is marked as a start of the degradation process of all doped BTESE materials and that the hybrid system remains intact until $500{ }^{\circ} \mathrm{C}$ in an inert nitrogen atmosphere.

Figure 5 shows the FT-IR spectra of doped and undoped BTESE powders calcined at $300{ }^{\circ} \mathrm{C}$ under nitrogen atmosphere. For all samples, $\mathrm{CH}_{2}$ vibrations at 1270 and $1413 \mathrm{~cm}^{-1}[1,38]$ are visible that can be regarded as evidence for the presence of $\mathrm{Si}-\mathrm{CH}_{2}-\mathrm{CH}_{2}-\mathrm{Si}$ in these samples. The signals at 1000 and $680 \mathrm{~cm}^{-1}$ are indicative for a $\mathrm{Si}-\mathrm{O}-\mathrm{Si}$ structure in the samples $[38,39]$. The $\mathrm{B}-\mathrm{O}$ stretching mode at $1467 \mathrm{~cm}^{-1}$ is reported in literature for boron-silica systems [26]. However, it was unable to find any proof of $\mathrm{B}-\mathrm{O}$ in the hybrid silica matrix. For $\mathrm{Nb}-$ BTESE and Ta-BTESE, there was no indication either of any change in the hybrid structure by the inclusion of these elements, as also reported elsewhere [24]. From these results, it can be concluded that all the dopants added to the BTESE did not disturb the hybrid silica network and that the central hinge of hybrid silica structure (i.e., ethylene bridge) is retained in all the doped BTESE samples.

Figure 6 shows cross-sectional HR-SEM micrographs of Nb-BTESE, Ta-BTESE and B-BTESE membranes. These membranes were fabricated using an identical dip-sol concentration of $0.3 \mathrm{M}$ and an almost identical particle size distribution. Therefore, any variation in thickness of the

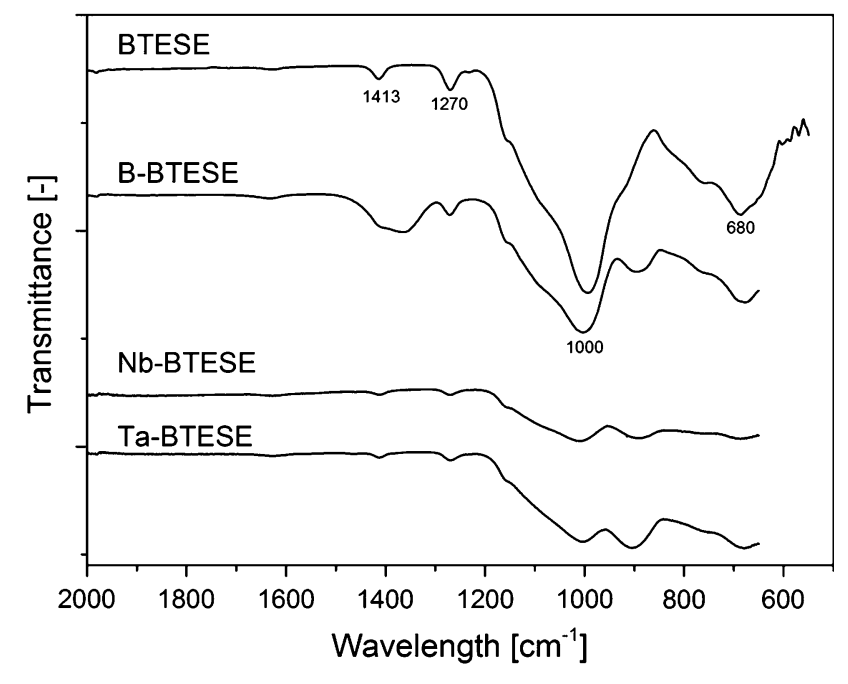

Fig. 5 Fourier transform IR spectra of undoped and doped BTESE powders after calcination in nitrogen at $300{ }^{\circ} \mathrm{C}$

selective layer can be ascribed to the effect of doping into the hybrid silica matrix. The separation layers showed thicknesses of 360, 230 and $180 \mathrm{~nm}$ for, respectively, $\mathrm{Nb}$ BTESE, Ta-BTESE and B-BTESE membranes. However, there might also be a possibility that differences in selective layer thickness can be due to the difference in solid contents of doped material in the sol. The undoped BTESE membrane formed a uniform selective layer of about $260 \mathrm{~nm}$ [33].

\subsection{Doped BTESE membrane characterization}

Single gas permeation experiments of Nb-BTESE, TaBTESE and B-BTESE membranes were performed at $200{ }^{\circ} \mathrm{C}$. These results as well as those of undoped BTESE (taken from Ref. [33]) are given in Table 1 and Fig. 7. In this way, the pore sizes of these membranes can be compared.

The Nb-BTESE and Ta-BTESE membranes were impermeable to sulfur hexafluoride $\left(\mathrm{SF}_{6}\right)$ gas molecules which ensured that the pore sizes of these membranes were smaller than $0.55 \mathrm{~nm}$. B-BTESE membranes showed some $\mathrm{SF}_{6}$ permeance from which it can be concluded that the B-BTESE membrane contains a few pores larger than $0.55 \mathrm{~nm}$. The presence of pinholes or defects in the selective layer was not visible by high-resolution SEM, and therefore, it can be stated that the inclusion of boron resulted in the formation of relative larger pores when synthesized by sol-gel processing.

It was surprising to observe similar gas permeance values for all membranes because the B-BTESE membrane has a relatively thin selective layer compared with the other doped and undoped BTESE membranes. The overall $\mathrm{H}_{2} / \mathrm{X}$ gas permselectivity of all doped BTESE membranes was 


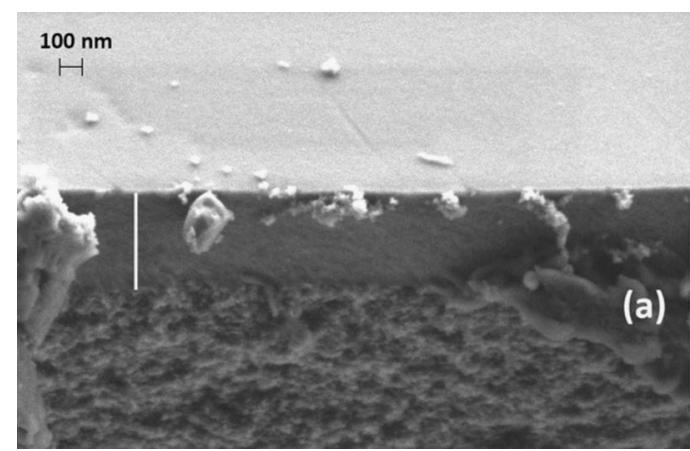

Fig. 6 Cross-sectional HR-SEM micrographs of doped BTESEderived membranes. a Nb-BTESE membrane with a selective layer thickness of about $360 \mathrm{~nm}$, b Ta-BTESE derived with the selective
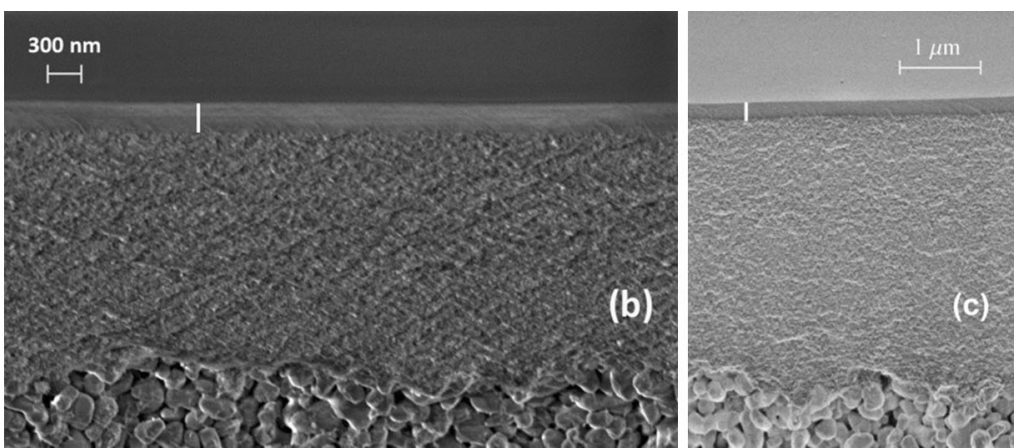

layer thickness of about $230 \mathrm{~nm}$ and c B-BTESE membrane with a selective layer thickness of about $180 \mathrm{~nm}$

Table 1 Single gas permeation and permselectivity results at $200{ }^{\circ} \mathrm{C}$ of doped BTESE developed with an identical dip-sol concentration

\begin{tabular}{|c|c|c|c|c|c|c|c|c|}
\hline \multirow[t]{2}{*}{$\begin{array}{l}\text { Gas kinetic diameter } \\
(\mathrm{nm})\end{array}$} & $\begin{array}{l}\text { Gas permeance } \\
\left(10^{-7} \mathrm{~mol} /\right. \\
\left.\mathrm{m}^{2} \mathrm{~s} \mathrm{~Pa}\right) \\
\text { BTESE }[33]\end{array}$ & $\begin{array}{l}\text { Selectivity } \\
\mathrm{H}_{2} / \mathrm{X}\end{array}$ & $\begin{array}{l}\text { Gas permeance } \\
\left(10^{-7} \mathrm{~mol} /\right. \\
\left.\mathrm{m}^{2} \mathrm{~s} \mathrm{~Pa}\right) \\
\mathrm{B}-\mathrm{BTESE}\end{array}$ & $\begin{array}{l}\text { Selectivity } \\
\mathrm{H}_{2} / \mathrm{X}\end{array}$ & $\begin{array}{l}\text { Gas permeance } \\
\left(10^{-7} \mathrm{~mol} /\right. \\
\left.\mathrm{m}^{2} \mathrm{~s} \mathrm{~Pa}\right) \\
\text { Ta-BTESE }\end{array}$ & $\begin{array}{l}\text { Selectivity } \\
\mathrm{H}_{2} / \mathrm{X}\end{array}$ & $\begin{array}{l}\text { Gas permeance } \\
\left(10^{-7} \mathrm{~mol} /\right. \\
\left.\mathrm{m}^{2} \mathrm{~s} \mathrm{~Pa}\right) \\
\mathrm{Nb}-\mathrm{BTESE}\end{array}$ & $\begin{array}{l}\text { Selectivity } \\
\mathrm{H}_{2} / \mathrm{X}\end{array}$ \\
\hline & $\delta=260 \mathrm{~nm}$ & & $\delta=180 \mathrm{~nm}$ & & $\delta=230 \mathrm{~nm}$ & & $\delta=360 \mathrm{~nm}$ & \\
\hline $\mathrm{He}=0.26$ & 2.52 & 1.23 & 3.88 & 1.28 & 4.06 & 1.39 & 3.92 & 1.28 \\
\hline $\mathrm{H}_{2}=0.289$ & 3.12 & 1 & 4.98 & 1 & 5.65 & 1 & 5.03 & 1 \\
\hline $\mathrm{CO}_{2}=0.33$ & 0.8 & 3.9 & 1.24 & 4 & 1.56 & 3.6 & 1.43 & 3.5 \\
\hline $\mathrm{N}_{2}=0.364$ & 0.23 & 13.5 & 0.43 & 11.5 & 0.81 & 7 & 0.77 & 6.5 \\
\hline $\mathrm{CH}_{4}=0.369$ & 0.16 & 19.5 & 0.39 & 12.7 & 0.46 & 12.3 & 0.42 & 12 \\
\hline $\mathrm{SF}_{6}=0.55$ & * & $\infty$ & 0.01 & 500 & $*$ & $\infty$ & $*$ & $\infty$ \\
\hline
\end{tabular}

The results are compared with undoped BTESE-derived membranes [33]

Gas detection limit of equipment: $5 \times 10^{-10} \mathrm{~mol} / \mathrm{m}^{2} \mathrm{~s} \mathrm{~Pa}$

* Below detection limit of equipment

$\infty$ Infinite permselectivity

lower than for undoped BTESE membranes (see Table 1). Nb-BTESE and Ta-BTESE membranes showed identical $\mathrm{H}_{2} / \mathrm{N}_{2}$ and $\mathrm{H}_{2} / \mathrm{CH}_{4}$ permselectivities. The incorporation of $\mathrm{Nb}$ and $\mathrm{Ta}$ in the hybrid silica matrix appears to form a similar pore microstructure but with a difference of almost $100 \mathrm{~nm}$ in the selective layer thickness.

The Nb-BTESE membrane showed far more permeance of bigger gas molecules (i.e., $\mathrm{CO}_{2}, \mathrm{~N}_{2}$, and $\mathrm{CH}_{4}$ ) than the undoped BTESE membranes, despite having a thicker selective layer (see Table 1). The degree of pore uniformity of the $\mathrm{Nb}$ BTESE selective layer was homogenous as no $\mathrm{SF}_{6}$ permeance was observed through the membrane, indicating that average pore size of the membrane was below $0.55 \mathrm{~nm}$. However, these values are far below in performance when compared with the work previously done on Nb-BTESE membranes $[24,25]$. This difference in membrane performance could be due to the synthesis recipe of Nb-BTESE sols that lead to a relatively loose pore size distribution, or due to the difference in the properties of support layer (average pore size and pore size distribution of $\gamma-\mathrm{Al}_{2} \mathrm{O}_{3}$ support).
To enhance the selectivity of doped BTESE membranes reported in this work, thermal treatment higher than $300{ }^{\circ} \mathrm{C}$, or for much longer holding times than $3 \mathrm{~h}$ at $300{ }^{\circ} \mathrm{C}$, could be beneficial because the pore shrinkage due to thermal treatment might improve the gas permselectivity of these membranes. However, extreme care must be taken regarding the degradation of the ethylene bridge. Although as it has been reported that the ethylene bridge might show decomposition at $470-480{ }^{\circ} \mathrm{C}$ [37], it is not known yet at which temperature the degradation actually starts.

\section{Conclusions}

Three different membrane materials (B-BTESE, TaBTESE and Nb-BTESE) were fabricated by sol-gel processing, and its applicability for gas separation was assessed by making microporous membranes through a single dipping procedure. All the doped BTESE sols formed a homogeneous selective layer of few hundred nanometers, 


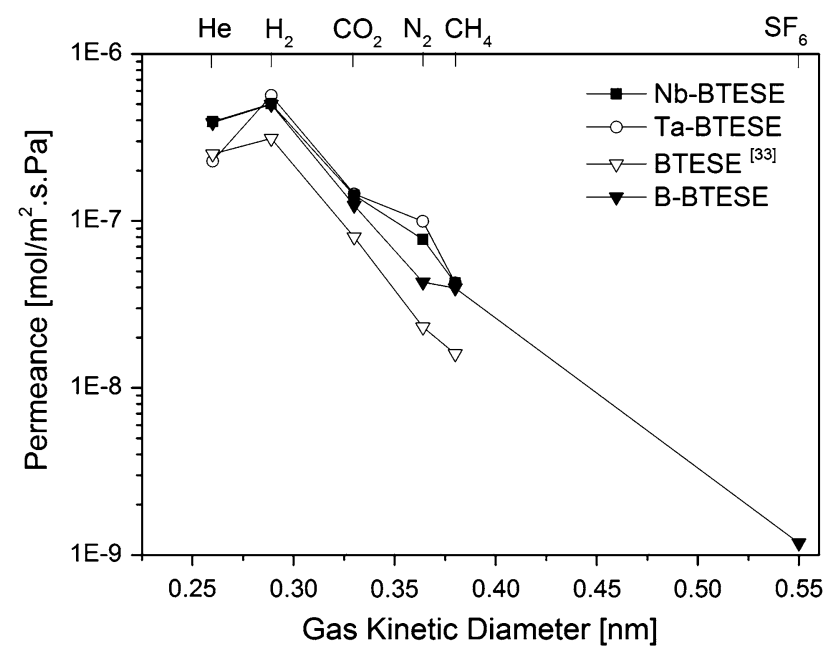

Fig. 7 Single gas permeation analysis of Nb-BTESE, Ta-BTESE and B-BTESE sol-gel-derived membranes (calcined in nitrogen at $300{ }^{\circ} \mathrm{C}$, with identical dip-sol concentration) as a function of gas kinetic diameter of permeating gas molecules measured at $200{ }^{\circ} \mathrm{C}$. The results are compared with undoped sol-gel-derived BTESE membranes [33]

as determined by high-resolution SEM micrographs. The structural evaluation by FT-IR spectroscopy of gels dried and calcined at $300{ }^{\circ} \mathrm{C}$ indicated that the ethylene bridge remains persistent in the silica backbone of BTESE for all systems. SGP analysis of Ta-BTESE and Nb-BTESE membranes indicated a defect-free pore microstructure with comparable $\mathrm{H}_{2} / \mathrm{N}_{2}$ and $\mathrm{H}_{2} / \mathrm{CH}_{4}$ permselectivities of 7 and 12, respectively. The boron-doped BTESE membranes had a relatively open pore microstructure that limits their application for gas separation applications. No effect of niobium doping on a decrease in $\mathrm{CO}_{2}$ permeance was found, i.e., lower $\mathrm{CO}_{2}$ permeance when compared with nitrogen and methane permeances, as observed by Qi et al. $[24,25,40]$ for some cases. It therefore remains unclear if incorporation of niobium in a hybrid silica matrix imparts any significant effect on lowering the $\mathrm{CO}_{2}$ permeance.

Acknowledgments This research was supported by Netherlands Technology Foundation (STW). We are grateful to Mark Smithers (Laboratory for Materials Characterization at the MESA+ Institute for Nanotechnology) for capturing high-resolution SEM images.

Open Access This article is distributed under the terms of the Creative Commons Attribution License which permits any use, distribution, and reproduction in any medium, provided the original author(s) and the source are credited.

\section{References}

1. Vos RM, Maier WF, Verweij H (1999) Hydrophobic silica membranes for gas separation. J Membr Sci 158:277-288

2. Scholes CA, Kentish SE, Stevens GW (2008) Carbon dioxide separation through polymeric membrane systems for flue gas applications. Recent Pat Chem Eng 1:52-56
3. Burggraaf AJ, Cot L (1996) Fundamentals of inorganic membrane science and technology (Series 4). Elsevier, Amsterdam. ISBN 978-0-444-81877-5

4. Zaman J, Chakma A (1994) Inorganic membrane reactors. J Membr Sci 92:1-28

5. Liu K, Song C, Subramani V (2009) Hydrogen and syngas production and purification technologies. Wiley, New Jersey. ISBN 9780470561256

6. Gavalas GR, Megiris CE, Nam SW (1989) Deposition of $\mathrm{H}_{2-}$ permselective $\mathrm{SiO}_{2}$ films. Chem Eng Sci 44:1829-1835

7. Tsapatsis M, Gavalas G (1994) Structure and aging characteristics of $\mathrm{H}_{2}$-permselective $\mathrm{SiO}_{2}-$ Vycor membranes. J Membr Sci $87: 281-296$

8. Uhlhorn RJR, Veld MHBJH, Keizer K, Burggraaf AJ (1992) Synthesis of ceramic membranes. J Mater Sci 27:527-537

9. Brinker CJ, Sehgal R, Hietala SL, Deshpande R, Smith DM, Loy D, Ashley CS (1994) Sol-gel strategies for controlled porosity inorganic materials. J Membr Sci 94:85-102

10. Klein LC, Gallagher D (1988) Pore structures of sol-gel silica membranes. J Membr Sci 39:213-220

11. Tsuru T (2008) Nano/subnano-tuning of porous ceramic membranes for molecular separation. J Sol-Gel Sci Technol 46:349-361

12. Castricum HL, Sah A, Kreiter R, Blank DHA, Vente JF, Elshof JET (2008) Hybrid ceramic nanosieves: stabilizing nanopores with organic links. Chem Commun 9:1103-1105

13. Castricum HL, Sah A, Geenevasen JAJ, Kreiter R, Blank DHA, Vente JF, Elshof JE (2008) Structure of hybrid organic-inorganic sols for the preparation of hydrothermally stable membranes. J Sol-Gel Sci Technol 48:11-17

14. Castricum HL, Kreiter R, van Veen HM, Blank DHA, Vente JF, ten Elshof JE (2008) High-performance hybrid pervaporation membranes with superior hydrothermal and acid stability. J Membr Sci 324:111-118

15. Castricum HL, Paradis GG, Mittelmeijer-Hazeleger MC, Kreiter R, Vente JF, Elshof JET (2011) Tailoring the separation behavior of hybrid organosilica membranes by adjusting the structure of the organic bridging group. Adv Funct Mater 21:2319-2329

16. Fotou GP, Lin YS, Pratsinis SE (1995) Hydrothermal stability of pure and modified microporous silica membranes. J Mater Sci 30:2803-2808

17. Yoshida K, Hirano Y, Fujii H, Tsuru T, Asaeda M (2001) Hydrothermal stability and performance of silica-zirconia membranes for hydrogen separation in hydrothermal conditions. J Chem Eng Jpn 34:523-530

18. Asaeda M, Sakou Y, Yang J, Shimasaki K (2002) Stability and performance of porous silica-zirconia composite membranes for pervaporation of aqueous organic solutions. J Membr Sci 209:163-175

19. Boffa V, Blank D, Tenelshof J (2008) Hydrothermal stability of microporous silica and niobia-silica membranes. J Membr Sci 319:256-263

20. Boffa V, Elshof JET, Petukhov AV, Blank DHA (2008) Microporous niobia-silica membrane with very low $\mathrm{CO}_{2}$ permeability. ChemSusChem 1(5):437-443

21. Kanezashi M, Asaeda M (2006) Hydrogen permeation characteristics and stability of Ni-doped silica membranes in steam at high temperature. J Membr Sci 271:86-93

22. Igi R, Yoshioka T, Ikuhara YH, Iwamoto Y, Tsuru T (2008) Characterization of Co-doped silica for improved hydrothermal stability and application to hydrogen separation membranes at high temperatures. J Am Ceram Soc 91(9): 2975-2981

23. Battersby S, Duke MC, Liu S, Rudolph V, da Costa JCD (2008) Metal doped silica membrane reactor: operational effects of 
reaction and permeation for the water gas shift reaction. J Membr Sci 316:46-52

24. Qi H, Han J, Xu N, Bouwmeester HJM (2010) Hybrid organicinorganic microporous membranes with high hydrothermal stability for the separation of carbon dioxide. ChemSusChem 3:1375-1378

25. Qi H, Han J, Xu N (2011) Effect of calcination temperature on carbon dioxide separation properties of a novel microporous hybrid silica membrane. J Membr Sci 382:231-237

26. Barboiu C, Sala B, Bec S, Pavan S, Petit E, Colomban P, Sanchez J, de Perthuis S, Hittner D (2009) Structural and mechanical characterizations of microporous silica-boron membranes for gas separation. J Membr Sci 326:514-525

27. Cotton FA, Wilkinson G, Murillo CA, Bochmann M (1998) Advanced inorganic chemistry, 5th edn. Wiley, New Jersey

28. Tietz TE, Wilson JW (1965) Behavior and properties of refractory metals, Tokyo University International Edition no. 6. University of Tokyo Press, Tokyo

29. Alers GB, Werder DJ, Chabal Y, Lu HC, Gusev EP, Garfunkel E, Gustafsson T, Urdahl RS (1998) Intermixing at the tantalum oxide/silicon interface in gate dielectric structures. Appl Phys Lett 73:1517-1519

30. Ueno K, Abe S, Onoki R, Saiki K (2005) Anodization of electrolytically polished Ta surfaces for enhancement of carrier injection into organic field-effect transistors. J Appl Phys 98:114503-1-114503-5

31. Devine RAB, Chaneliere C, Autran JL, Balland B, Paillet P, Leray JL (1997) Use of carbon-free $\mathrm{Ta}_{2} \mathrm{O}_{5}$ thin-films as a gate insulator. Microelectron Eng 36:61-64
32. Wolf MJ, Roitsch S, Mayer J, Nijmeijer A, Bouwmeester HJM (2013) Fabrication of ultrathin films of $\mathrm{Ta}_{2} \mathrm{O}_{5}$ by a sol-gel method. Thin Solid Films 527:354-357

33. Qureshi HF, Nijmeijer A, Winnubst L (2013) Influence of sol-gel process parameters on the micro-structure and performance of hybrid silica membranes. J Membr Sci 446:19-25

34. de Vos RM, Verweij H (1998) High-selectivity high-flux silica membranes for gas separation. Science 279:1710-1711

35. Cao GZ, Meijerink J, Brinkman HW, Burggraaf AJ (1993) Permporometry study on the size distribution of active pores in porous ceramic membranes. J Membr Sci 83:221-235

36. Miller JB, Ko EI (1997) Control of mixed oxide textural and acidic properties by the sol-gel method. Catal Today 35:269-292

37. Kanezashi M, Yada K, Yoshioka T, Tsuru T (2010) Organicinorganic hybrid silica membranes with controlled silica network size: preparation and gas permeation characteristics. J Membr Sci 348:310-318

38. Medda SK, Kundu D, De G (2003) Inorganic-organic hybrid coatings on polycarbonate.: spectroscopic studies on the simultaneous polymerizations of methacrylate and silica networks. J Non-Cryst Solids 318:149-156

39. Karmakar B, De G, Ganguli D (2000) Dense silica microspheres from organic and inorganic acid hydrolysis of TEOS. J Non-Cryst Solids 272:119-126

40. Qi H, Chen H, Li L, Zhu G, Xu N (2012) Effect of Nb content on hydrothermal stability of a novel ethylene-bridged silsesquioxane molecular sieving membrane for $\mathrm{H}_{2} / \mathrm{CO}_{2}$ separation. J Membr Sci 421-422:190-200 